\title{
Preoperative Endoscopic Third Ventriculostomy in Children with Posterior Fossa Tumors: An Institution Experience
}

\author{
Posterior Fossa Tümörlü Çocuklarda Preoperatif Endoskopik Üçüncü \\ Ventrikülostomi: Bir Kurum Deneyimi
}

Waleed AZAB, Tarek AL-SHEIKH, Ahmed YAHIA

Ibn Sina Hospital, Department of Neurosurgery, Kuwait

Corresponding Author: Waleed AZAB / E-mail: waleedazab@hotmail.com

\begin{abstract}
AIM: To assess the effectiveness and safety of pre-resection endoscopic third ventriculostomy (ETV) in permanently relieving hydrocephalus in children with posterior fossa tumors.

MATERIAL and METHODS: 17 pediatric patients with posterior fossa tumors and associated triventricular obstructive hydrocephalus underwent ETV before definitive tumor resection, and ETV was repeated after tumor resection if hydrocephalus with increased intracranial pressure persisted or recurred. The medical records, operative notes and imaging studies were retrospectively reviewed.

RESULTS: 18 ETV procedures were performed in 17 patients, consisting of 11 males and 6 females, age range (1.5 to 13 years; mean $6 \pm 3.86$ ). Follow-up periods ranged from 6 to 23 months (mean follow-up 13.9 \pm 5.4 months). ETV was successful in relieving hydrocephalus during the follow-up period in 15 out of 17 patients (88.2\%). Prior to surgical excision of the posterior fossa tumors, no failures of ETV were detected and all of the 17 patients showed marked clinical improvement and radiological disappearance of signs of active hydrocephalus.

CONCLUSION: Preoperative ETV is a highly effective long-term CSF diversion procedure for treatment of hydrocephalus associated with posterior fossa tumors in children. In experienced hands, ETV has a very low complication rate.
\end{abstract}

KEYWORDS: Hydrocephalus, Endoscopic third ventriculostomy, Posterior fossa tumor

öz

AMAÇ: Posterior fossa tümörlü çocuklarda hidrosefaliyi kalıcı olarak tedavi etmek üzere rezeksiyon öncesi endoskopik üçüncü ventrikülostominin (ETV) etkinlik ve güvenliğini değerlendirme.

YÖNTEM ve GEREÇLER: Posterior fossa tümörlü ve ilişkili triventriküler obstrüktif hidrosefalili 17 pediatrik hastada kesin tümör rezeksiyonu öncesinde ETV yapıldı ve ETV işlemi eğer artmış intrakraniyal basınçlı hidrosefali devam ediyorsa veya tekrarlarsa tümör rezeksiyonu sonrasında tekrarlandı. Tıbbi kayıtlar, ameliyat notları ve görüntüleme çalışmaları retrospektif olarak gözden geçirildi.

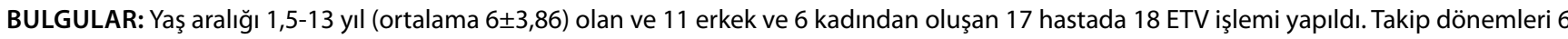

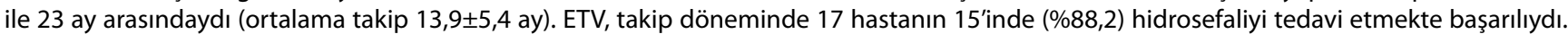
Posterior fossa tümörlerinin cerrahi insizyonu öncesinde herhangi bir ETV başarısızlığı saptanmadı ve 17 hastanın tümünde belirgin klinik iyileşme ve aktif hidrosefali bulgularının radyolojik olarak kaybolması görüldü.

SONUÇ: Preoperatif ETV çocuklarda posterior fossa tümörleriyle ilişkili hidrosefalinin tedavisinde çok etkin, uzun dönemli bir BOS diversiyonu işlemidir. Deneyimli ellerde, ETV'nin komplikasyon oranı çok düşüktür

ANAHTAR SÖZCÜKLER: Hidrosefali, Endoskopik üçüncü ventrikülostomi, Posterior fossa tümörü

\section{INTRODUCTION}

Internal CSF diversion using endoscopic third ventriculostomy (ETV) evolved as an appealing management option of obstructive hydrocephalus associated with posterior fossa tumors (21). As an alternative procedure to either ventriculoperitoneal (VP) shunting or external ventricular drainage (EVD), ETV has been found very effective for the emergency control of severe hydrocephalus in these patients since it can quickly eliminate symptoms (19).
Controversy, however, still exists regarding the routine use of ETV prior to tumor resection and some authors still even prefer preoperative VP shunts or EVD (1). The purpose of the present study was to assess the effectiveness and safety of pre-resection ETV in permanently relieving hydrocephalus in children with posterior fossa tumors.

\section{PATIENTS and METHODS}

A total of 17 pediatric patients presented to our institution with posterior fossa tumors and associated triventricular 
obstructive hydrocephalus during the period between February 2008 and February 2010. All patients underwent ETV within a period of 2 to 5 days before definitive tumor resection, and ETV was repeated after tumor resection if hydrocephalus with increased intracranial pressure persisted or recurred. The decision to perform ETV was based on the clinical evidence of high intracranial pressure and radiological demonstration of active triventricular hydrocephalic process irrespective of the suspected radiological diagnosis of tumor pathology. The medical records, operative notes and imaging studies were retrospectively reviewed.

\section{Surgical Procedure}

The surgical technique for ETV is extensively described in the literature $(9,10,11)$. In short, the technique used (Figure 1A-F) is described in the following paragraphs. All procedures were done under general anaesthesia with the patient in supine position; head is flexed $15^{\circ}$ and otherwise in a neutral position on a horse-shoe head rest. A vertical skin incision was made with its center over the Kocher's point. A rigid endoscope with $0^{\circ}$ degree lens was used for all procedures (Ventriculoscope ${ }^{\circ}$, Aesculap, Tuttlingen, Germany). The Fogarty balloon catheters used for opening the third ventricular floor were 3 or 4F. After entering the lateral ventricle, the endoscope was navigated through the foramen of Monro identifying the anatomical features in the floor of the third ventricle. The endoscope was advanced closer to the floor and a point for puncturing was chosen; usually midway between the mamillary bodies and the infundibular recess in a thinned out translucent area of the floor using the tip of the Fogarty catheter. The balloon was then slowly inflated within the hole of the third ventricular floor by means of a saline filled syringe until a stoma sufficient to accommodate the outer diameter of the endoscope is accomplished and vibrating edges and the whirl sign were seen. The endoscope was advanced through the stoma and Liliequist membrane was punctured if present to ensure the patency of the ventriculostomy and the prepontine cistern was inspected. Then the endoscope was withdrawn after making sure that the ventricular cavities were clear of blood and the scalp incision was closed in layers.

Follow-up data used in the study consisted of clinical examination findings and computed tomography (CT) scans. Clinically, success was defined as resolution of the signs and symptoms of hydrocephalus during the whole follow-up period. Failure was defined as persistence or worsening of the clinical signs and symptoms of hydrocephalus requiring shunt insertion or documented ETV-related complications. Radiological success was defined as resolution of the preoperative radiological signs of hydrocephalus and signs of increased intracranial pressure (ICP) in a CT scan obtained at least three days postoperatively in the absence of cerebrospinal fluid (CSF) leak.

Statistical evaluation was performed using Microsoft ${ }^{\circ}$ Excel software, version 2007.

\section{RESULTS}

A total of 18 ETV procedures were performed in 17 patients. The patient population consisted of 11 males and 6 females with an age range from 1.5 to 13 years and a mean age of $6 \pm 3.86$ years. Clinical findings at presentation are presented in Table I. The types of posterior fossa tumors included ependymoma $41.2 \%$ (7/17), cerebellar astrocytoma $35.3 \%$ $(6 / 17)$, medulloblastoma $17.6 \%(3 / 17)$ and diffuse pontine glioma 5.9\% (1/17) (Table II, Figure 2). The follow-up periods ranged from 6 to 23 months with a mean follow-up of 13.9 \pm 5.4 months.
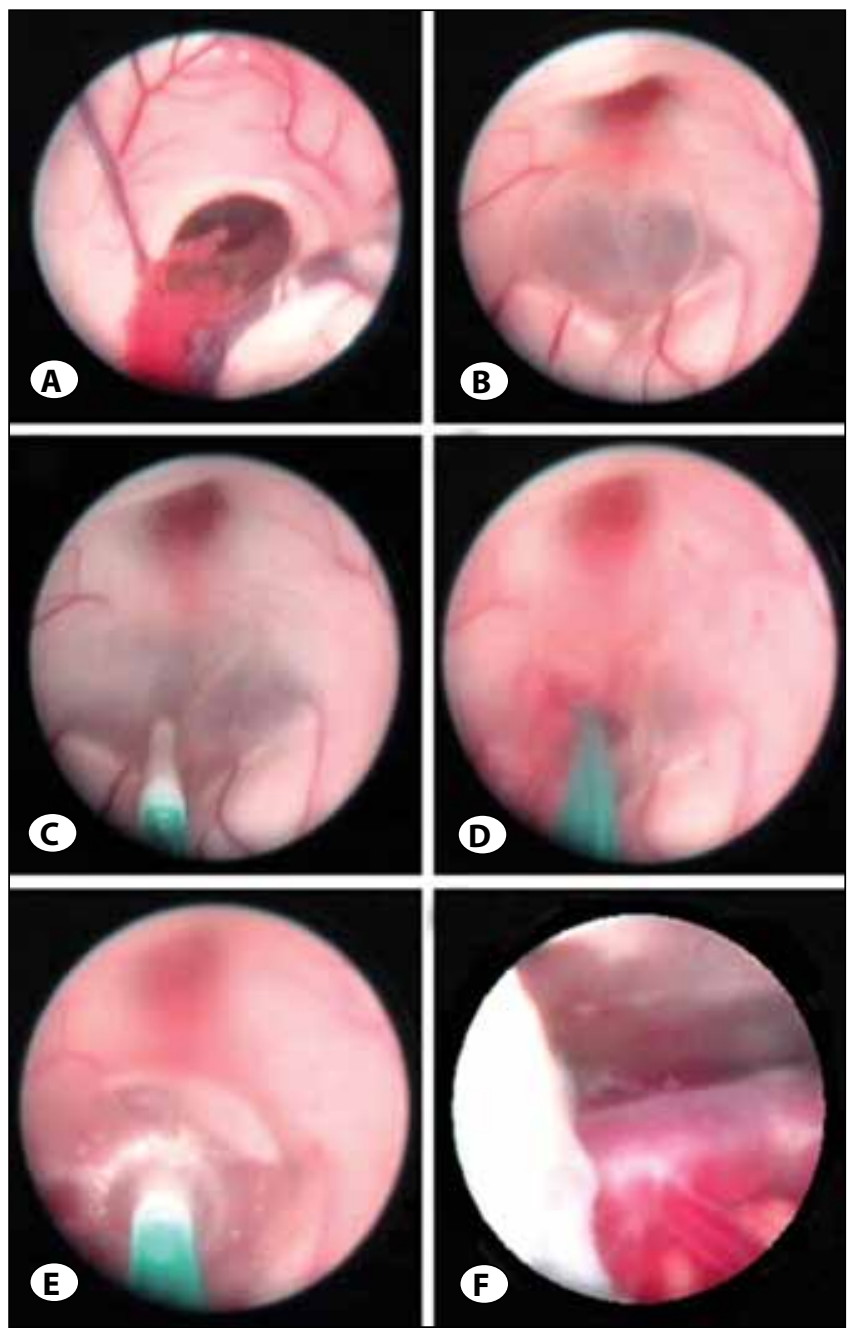

Figure 1: Surgical technique of endoscopic third ventriculostomy (case 3). (A) Endoscopic view of the foramen of Monro and the structures in its vicinity. (B) The floor of the third ventricle seen after passing the endoscope through the foramen of Monro. (C) The tip of the Fogarty balloon catheter points to the chosen point of puncturing the ventricular floor. (D) The third ventricular floor has been punctured. (E) The balloon is inflated to dilate the puncture created in the third ventricular floor. (F) The interpeduncular cistern as seen by the endoscope; the basilar, right posterior cerebral and right superior cerebellar arteries can be seen clearly. 
Table I: Clinical Findings of the Study Population by the Time of Presentation

\begin{tabular}{|c|c|c|c|c|c|c|c|c|c|c|c|c|c|}
\hline \multirow[b]{2}{*}{ z } & \multirow[b]{2}{*}{ 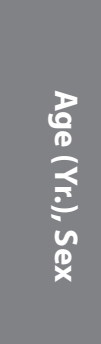 } & \multirow[b]{2}{*}{ 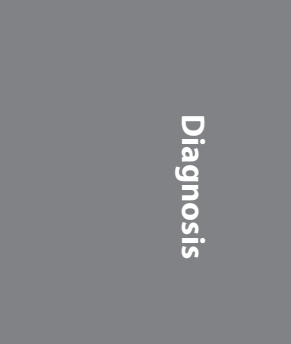 } & \multicolumn{11}{|c|}{ Clinical Features } \\
\hline & & & 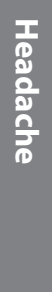 & 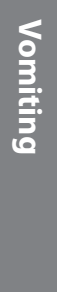 & $\begin{array}{l}\frac{5}{8} \\
\frac{0}{2} \\
\frac{2}{4}\end{array}$ & 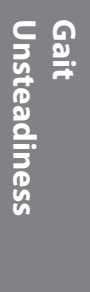 & $\begin{array}{l}\frac{0}{0} \\
\frac{0}{0} \\
\overline{0} \\
\frac{8}{8} \\
\frac{0}{3} \\
0\end{array}$ & 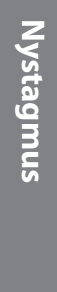 & 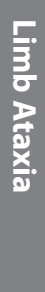 & $\begin{array}{l}\frac{3}{8} \\
\frac{2}{5} \\
\frac{8}{8} \\
\frac{8}{8} \\
\frac{2}{2}\end{array}$ & 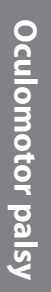 & $\begin{array}{l}\frac{7}{00} \\
\frac{0}{0} \\
\frac{2}{2} \\
\frac{0}{0} \\
\frac{0}{2}\end{array}$ & 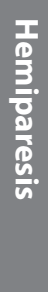 \\
\hline 1 & $11 \mathrm{M}$ & Ependymoma & - & + & - & - & - & + & - & - & - & - & - \\
\hline 2 & $6 \mathrm{M}$ & Cereb. astrocytoma & + & + & - & + & + & + & + & - & - & - & - \\
\hline 3 & $3 M$ & Medulloblastoma & + & - & + & + & + & + & + & - & - & - & - \\
\hline 4 & $2 \mathrm{M}$ & Medulloblastoma & - & + & + & - & - & - & - & + & - & - & + \\
\hline 5 & $7 F$ & Ependymoma & + & + & - & + & - & - & - & - & - & - & - \\
\hline 6 & $4 \mathrm{~F}$ & Ependymoma & - & + & - & - & + & + & - & - & - & - & - \\
\hline 7 & $12 \mathrm{M}$ & Diff. pont. glioma & + & - & + & + & - & + & - & - & + & + & + \\
\hline 8 & $13 \mathrm{~F}$ & Cereb. astrocytoma & + & - & - & + & + & & + & + & - & - & - \\
\hline 9 & $2 \mathrm{~F}$ & Ependymoma & - & + & + & - & - & + & + & - & - & - & - \\
\hline 10 & $13 \mathrm{M}$ & Cereb. astrocytoma & + & + & - & + & + & - & - & - & - & - & - \\
\hline 11 & $2.5 \mathrm{M}$ & Ependymoma & - & + & - & - & + & + & + & + & - & - & - \\
\hline 12 & $1.5 \mathrm{M}$ & Medulloblastoma & - & + & + & - & - & + & - & - & - & - & - \\
\hline 13 & $4 \mathrm{M}$ & Cereb. astrocytoma & + & - & - & + & + & - & - & - & - & - & - \\
\hline 14 & $7 F$ & Cereb. astrocytoma & + & + & - & + & + & + & + & + & - & - & - \\
\hline 15 & $3.5 \mathrm{M}$ & Ependymoma & + & - & - & + & + & - & - & - & - & - & - \\
\hline 16 & $4 \mathrm{M}$ & Cereb. astrocytoma & + & - & - & + & - & + & - & + & - & - & - \\
\hline 17 & $6.5 \mathrm{~F}$ & Ependymoma & + & + & - & - & - & + & + & - & - & - & - \\
\hline
\end{tabular}

Table II: Outcome of ETV and Follow-up Periods

\begin{tabular}{|c|c|c|c|c|}
\hline No. & Age (yr), Sex & Diagnosis & Outcome & Follow up period (Months) \\
\hline 1 & $11 \mathrm{M}$ & Ependymoma & Successful & 19 \\
\hline 2 & $6 \mathrm{M}$ & Cerebellar astrocytoma & Successful & 13 \\
\hline 3 & $3 M$ & Medulloblastoma & Failed & 6 \\
\hline 4 & $2 M$ & Medulloblastoma & Successful & 19 \\
\hline 5 & $7 F$ & Ependymoma & Successful & 16 \\
\hline 6 & $4 \mathrm{~F}$ & Ependymoma & Successful & 15 \\
\hline 7 & $12 \mathrm{M}$ & Diffuse pontine glioma & Successful & 7 \\
\hline 8 & $13 F$ & Cerebellar astrocytoma & Successful & 15 \\
\hline 9 & $2 \mathrm{~F}$ & Ependymoma & Failed & 20 \\
\hline 10 & $13 \mathrm{M}$ & Cerebellar astrocytoma & Successful & 18 \\
\hline 11 & $2.5 \mathrm{M}$ & Ependymoma & Successful & 10 \\
\hline 12 & $5.5 \mathrm{M}$ & Medulloblastoma & Successful & 22 \\
\hline 13 & $4 \mathrm{M}$ & Cerebellar astrocytoma & Successful & 23 \\
\hline 14 & $7 F$ & Cerebellar astrocytoma & Successful & 8 \\
\hline 15 & $8 M$ & Ependymoma & Successful & 13 \\
\hline 16 & $4 \mathrm{M}$ & Cerebellar astrocytoma & Successful & 7 \\
\hline 17 & $6.5 \mathrm{~F}$ & Ependymoma & Successful & 15 \\
\hline
\end{tabular}


No technical difficulties were encountered in fenestrating the floor of the third ventricle and the procedure was smoothly performed in all patients with no intraoperative complications.

ETV was successful in relieving hydrocephalus during the follow-up period in 15 out of 17 patients (88.2\%) (Figure 3). Prior to surgical excision of the posterior fossa tumors, no failures of ETV were detected and all of the 17 patients showed marked clinical improvement and radiological disappearance of the ventriculomegaly, CSF transependymal permeation and tight CSF spaces (Sylvian fissures and cortical sulci) (Figure 4A-D,5). Furthermore, a slack posterior fossa was noted upon surgical excision of the tumor.

Throughout the follow-up period, two post-tumor resection failures of ETV occurred. The first was a 3-year old male (Case 3) with a medulloblastoma who presented with manifestations of high ICP six months following tumor resection. A CT scan revealed a picture of obstructive hydrocephalus but the $4^{\text {th }}$ ventricle was patent and there was a non-enhancing left frontal mass with surrounding perifocal edema, causing significant mass effect (Figure $6 \mathrm{~A}-\mathrm{C}$ ). The patient underwent

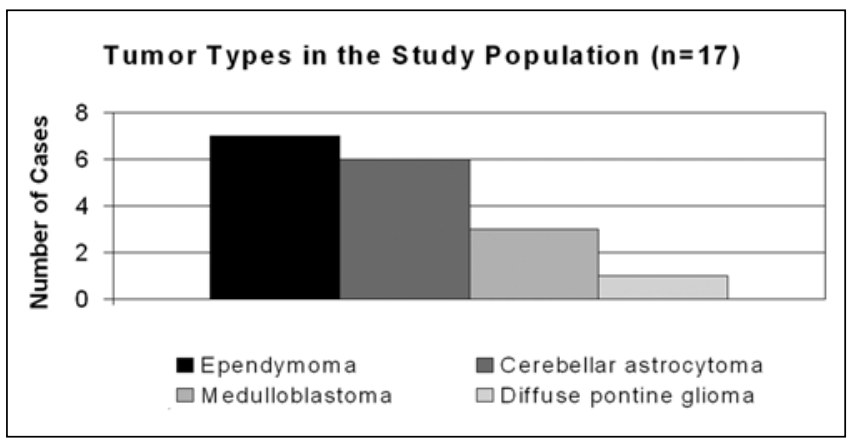

Figure 2: Bar graph of the frequency of the various tumor types in the study population.

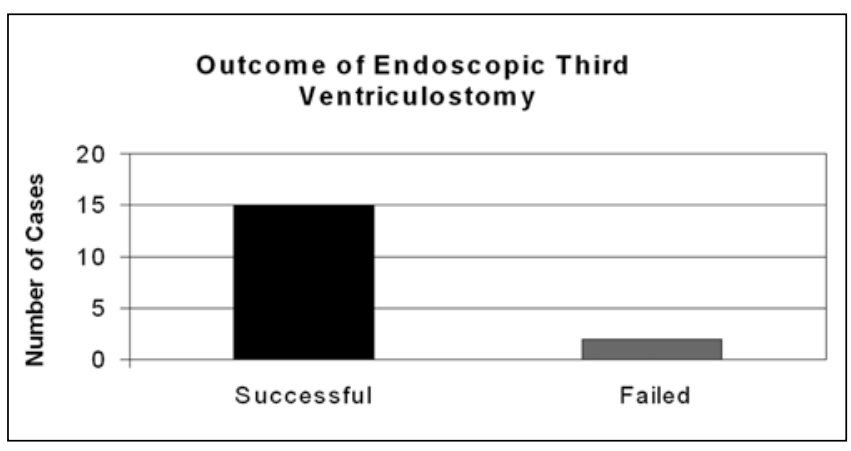

Figure 3: Outcome of ETV in the study population.

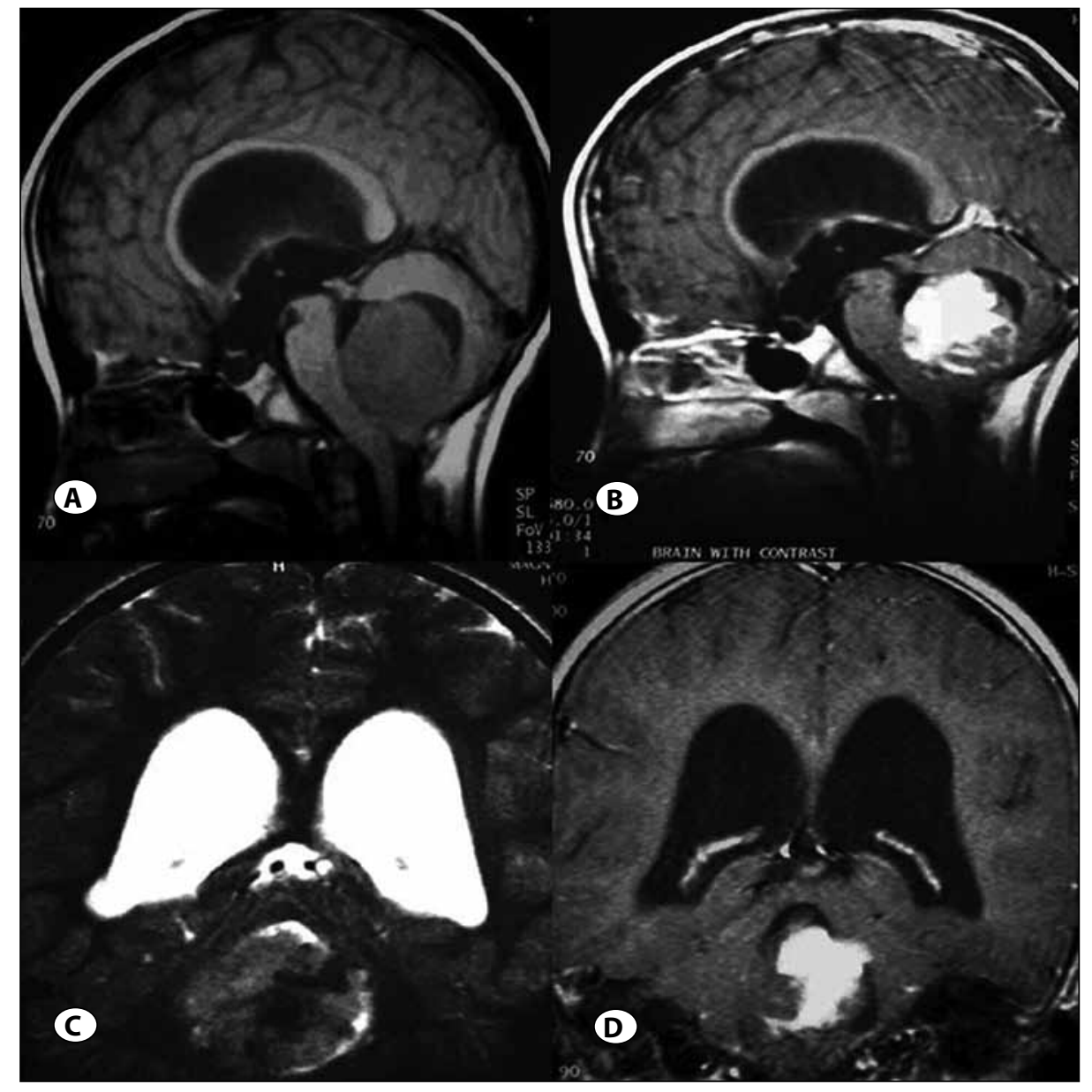

Figure 4: Preoperative MRI images of a patient with fourth ventricular medulloblastoma (Case 3). The tumor is seen obstructing the fourth ventricle with supratentorial hydrocephalus. (A) Sagittal $T_{1}$-weighted without contrast; (B) Sagittal T1-weighted with contrast; (C) Coronal $\mathrm{T}_{2}$-weighted; (D) Coronal T1-weighted with contrast images. 
a second ETV, which revealed a patent stoma of the $3^{\text {rd }}$ ventricular floor (even larger than the original opening). The AVP shunt was then inserted in the same setting. The second failed ETV took place in a 2-year old female patient with a $4^{\text {th }}$ ventricular ependymoma (Case 9) who developed CSF infection 5 days after tumor excision and was treated with EVD and antibiotics, followed by insertion of a VP shunt (Table II).

Complications directly related to the procedure were encountered in 2 patients ( 2 out of 18 ETV procedures; $11 \%$ ). One patient (Case 9) developed CSF infection as described above. Another patient (Case 5) developed a transient hyperphagia that resolved completely within six days.

\section{DISCUSSION}

The majority of children with posterior fossa tumors have hydrocephalus at the time of presentation (6). Management of hydrocephalus in these cases has been a longstanding controversy (17).

In the past, the insertion of a VP shunt was considered to be an appropriate preoperative treatment in children with posterior fossa tumors and associated hydrocephalus. However, the growing awareness of the common complications associated with ventricular shunting and the rarer complications specific to patients with posterior fossa tumors such as upward herniation, hemorrhage within the tumor and peritoneal seeding of the intracranial tumor cells caused neurosurgeons

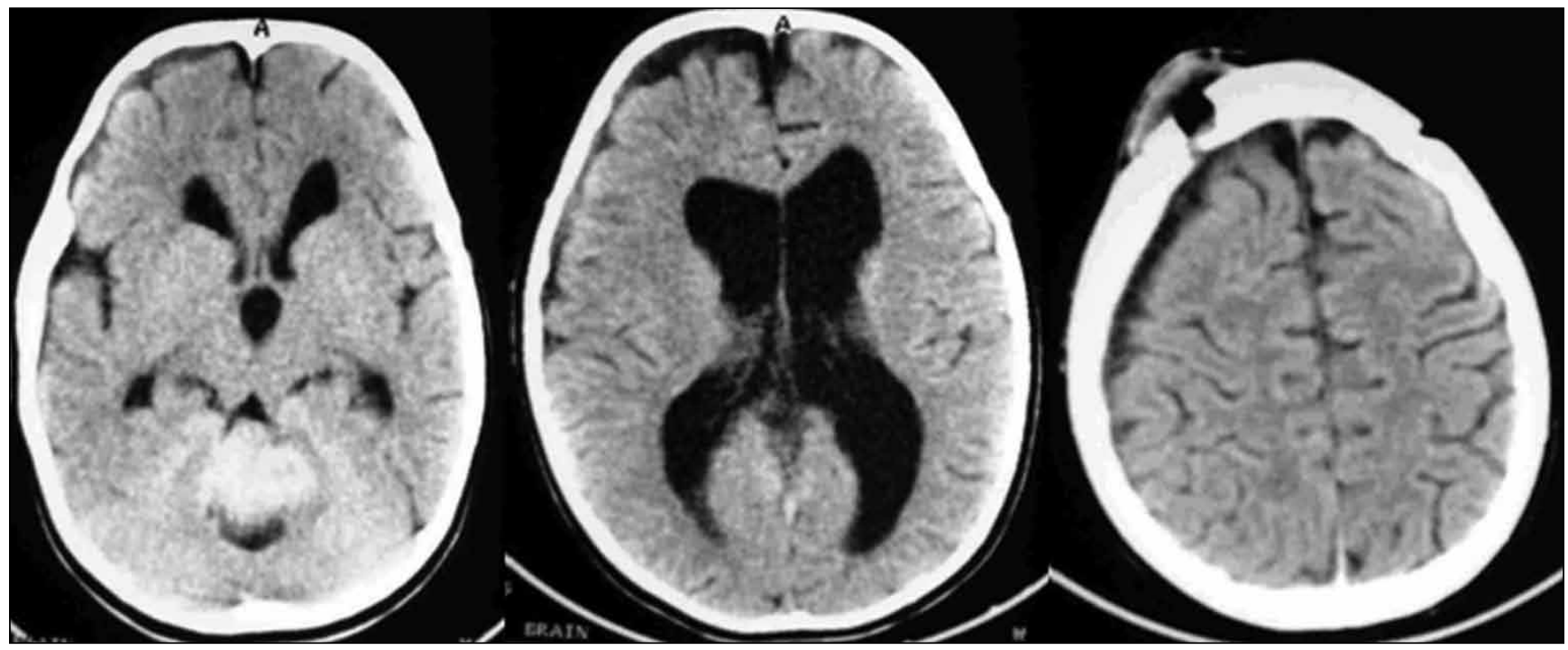

Figure 5: CT with contrast images of case No.3 after undergoing ETV before tumor resection. The subarachnoid spaces are widened and radiological signs of active hydrocephalus are absent.

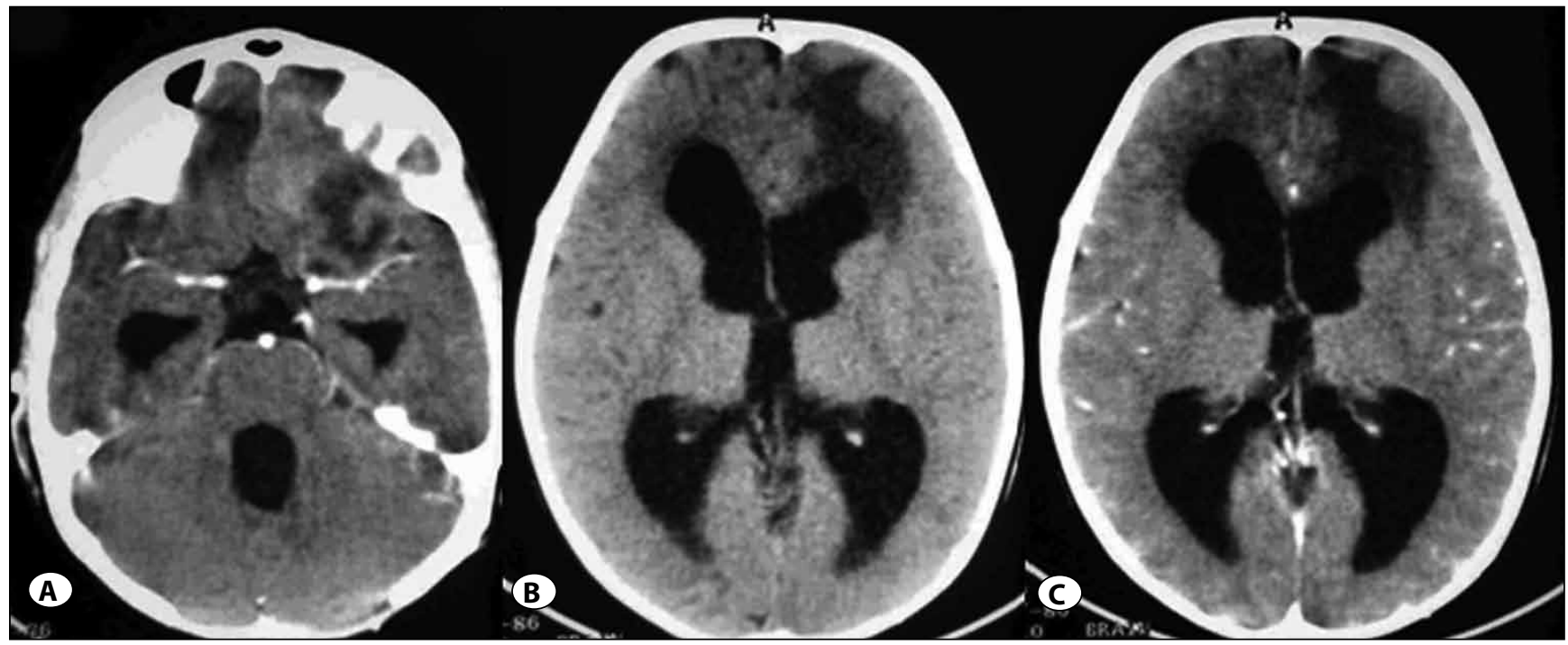

Figure 6: CT with images of case No.3 after 6 months (Case No.3). Note the absence of any residual or recurrent lesions in the fourth ventricle (A). A non-enhancing left frontal mass is seen along with tetraventricular hydrocephalus (B and C). 
to question the need for routine shunt insertion (20). Lee and colleagues retrospectively reviewed 42 children with medulloblastoma who were not shunted preoperatively and found that 17 patients (40\%) required permanent shunts within four weeks of craniotomy; comparing these patients to those who undergone preoperative VP shunts, a much higher rate of morbidity was noted in those without VP shunting. (13)

Another CSF diversion procedure that can be employed in children with posterior fossa tumors and associated hydrocephalus is insertion of an EVD routinely just prior to tumor resection (16). EVD is associated with risk of CSF infection, hemorrhage or upward herniation (20). Out of these complications, a trend towards a more expectant treatment policy became adopted and consisted of preoperative steroids followed by tumor excision and insertion of an EVD if needed (15).

Internal CSF diversion using ETV evolved as an appealing management option of obstructive hydrocephalus associated with posterior fossa tumors. Obstruction of the CSF flow at the level of the fourth ventricle provides the rationale for the curative effect of ETV in this patient population (21). ETV as an alternative procedure to either VP shunting or EVD has been found very effective for the emergency control of severe hydrocephalus caused by posterior fossa tumors since it can quickly eliminate symptoms (19) and has more recently been recommended by some authors as the first choice treatment option owing to shorter duration of surgery, lower morbidity, lower failure rate as well as the obviously significant advantage of avoiding shunt dependence (8). Success rates ranging from $50 \%$ to $95 \%$ have been reported in the literature $(2,7,9,11,19,21,22)$. In our series, a success rate of $88.2 \%$ was achieved.

Although ETV has been reported as a safe therapy that should be considered as a treatment option for persistent hydrocephalus after the surgical excision of posterior fossa tumors $(20,24)$, controversy still exists regarding its routine use prior to tumor resection (1). In a study of 59 patients with long-term follow-up periods, the use of pre-resectional ETV has been reported to be an effective and safe procedure with a high success rate at up to 7.5 years of follow-up (1). Although total resection of the tumor should restore the CSF pathway from the third ventricle to the subarachnoid space through the sylvian aqueduct and the fourth ventricle, a significant number of these children will ultimately have uncontrolled hydrocephalus following tumor resection $(5,13)$. It is postulated that the postoperative adhesions around the aqueduct or the fourth ventricle outlets might cause the persistence of the hydrocephalus (17). ETV prior to resection of posterior fossa tumors was found to reduce the risk of postoperative hydrocephalus and in turn reduce the incidences of morbidity and mortality in these patients $(18,21)$. Such reduction of the risk of postoperative hydrocephalus suggests that an additional prophylactic effect of preresectional ETV is in evidence; preoperative normalization of CSF hydrodynamics seems to decrease the risk of the development of permanent postoperative impairment of the CSF circulation (21). Furthermore, in children with posterior fossa tumors and associated active ventricular dilatation, awaiting the hydrocephalus to be relieved by tumor excision places them at risk of developing intracranial hypertension, an increased rate of CSF leakage, pseudomeningocele formation, prolonged hospitalization, and a higher rate of pseudobulbar palsy (13).

The need for CSF diversion prior to tumor resection was related to the type of tumor in one recent large study by Due-Tønnessen and Helseth who found a $87 \%$ cure rate of hydrocephalus by tumor resection alone in children with posterior fossa astrocytoma and a lower cure rate of hydrocephalus by tumor resection alone in patients with medulloblastoma and ependymoma, results which raise the issue of the actual need for preresection ETV in patients whose hydrocephalus can be treated by tumor excision alone (6).

ETV can be used as a palliative treatment in terminal patients with brainstem tumors including diffuse pontine gliomas, yielding good symptomatic relief without significant surgical morbidity (12). In this series, one patient with diffuse pontine glioma (case 7) experienced a marked symptomatic relief of high ICP after an ETV was performed.

A smooth intraoperative course with a slack posterior fossa was noted during tumor excision. No hydrocephalus, CSF leaks or pseudomeningoceles were present postoperatively. The complication rate of $11 \%$ encountered in this study fits well within the 6 to $20 \%$ range of complication rates reported in the literature (17). Although several serious and fatal complications have been reported including intraoperative venous or arterial bleeding, seizures, CSF leakage, infection, oculomotor nerve palsy, bradycardia, temperature regulation disturbance, diabetes insipidus, syndrome of inappropriate antidiuretic hormone, basilar artery perforation or traumatic aneurysm, subarachnoid, and subdural hematoma $(2,3,4,10,11,14,23,25)$, the complications of ETV in the majority of cases are usually clinically insignificant.

\section{CONCLUSION}

Preoperative ETV is a highly effective long-term CSF diversion procedure for treatment of hydrocephalus associated with posterior fossa tumors in children. In experienced hands, ETV has a very low complication rate. Further studies to justify the routine use of ETV prior to definitive tumor excision are needed to validate these observations.

\section{REFERENCES}

1. Bhatia $\mathrm{R}$, Tahir $\mathrm{M}$, Chandler $\mathrm{CL}$ : The management of hydrocephalus in children with posterior fossa tumours: The role of pre-resectional endoscopic third ventriculostomy. Pediatr Neurosurg 45: 186-191, 2009

2. Brockmeyer D, Abtin K, Carey L, Walker M: Endoscopic third ventriculostomy: An outcome analysis. Pediatr Neurosurg 28: 236-240, 1998 
3. Buxton N, Macarthur D, Mallucci C, Punt J, Vloeberghs M: Neuroendoscopic third ventriculostomy in patients less than 1 year old. Pediatr Neurosurg 29:73-76,1998

4. Cinalli G, Sainte-Rose $C$, Chumas P, Zerah M, Brunelle F, Lot G, Pierre-Kahn A, Renier D: Failure of third ventriculostomy in the treatment of aqueductal stenosis in children. J Neurosurg 90:448-454, 1999

5. Culley D, Berger M, Shaw D, Geyer R: An analysis of factors determining the need for ventriculouloperitoneal shunts after posterior fossa tumor surgery in children. Neurosurgery 34:402-408, 1994

6. Due-Tønnessen BJ, Helseth E: Management of hydrocephalus in children with posterior fossa tumors: Role of tumor surgery. Pediatr Neurosurg 43: 92-96, 2007

7. El Beltagy MA, Kamal HM, Taha H, Awad M, El Khateeb N: Endoscopic third ventriculostomy before tumor surgery in children with posterior fossa tumors, CCHE experience. Childs Nerv Syst 26: 1699-704, 2010

8. El-Ghandour NM: Endoscopic third ventriculostomy versus ventriculoperitoneal shunt in the treatment of obstructive hydrocephalus due to posterior fossa tumors in children. Childs Nerv Syst 27:117-26, 2011

9. Gangemi M, Donati P, Maiuri F, Longatti P, Godano U, Mascari C: Endoscopic third ventriculostomy for hydrocephalus. Minim Invasive Neurosurg 42:128-132, 1999

10. Grant J, Mclone D: Third ventriculostomy-A review. Surg Neurol 47:210-212, 1997

11. Hopf NJ, Grunert P, Fries G, Resch K, Perneczky A: Endoscopic third ventriculostomy: Outcome analysis of 100 consecutive procedures. Neurosurgery 44:795-804, 1999

12. Klimo P Jr, Goumnerova LC: Endoscopic third ventriculocisternostomy for brainstem tumors. J Neurosurg 105: 271-274, 2006

13. Lee M, Wisoff JH, Abbott R, Freed D, Epstein FJ: Management of hydrocephalus in children with medulloblastoma: Prognostic factors for shunting. Pediatr Neurosurg 20:240-247, 1994

14. McLaughlin MR, Wahlig JB, Kaufmann AM, Albright AL: Traumatic basilar aneurysm after endoscopic third ventriculostomy: Case report. Neurosurgery 41:1400-1404, 1997

15. Muszynski C, Laurent J, Cheek W: Effects of ventricular drainage and dural closure on cerebrospinal fluid leaks after posterior fossa tumor surgery. Pediatr Neurosurg 21:227-231, 1994
16. Pang D: Medulloblastoma. In: Cohen A (ed), Surgical Disorders of the Fourth Ventricle. Cambridge, Massachussetts: Blackwell Science, 1996: 168-188

17. Ray P, Jallo GI, Kim RY, Kim BS, Wilson S, Kothbauer K, Abbott $\mathrm{R}$ : Endoscopic third ventriculostomy for tumor-related hydrocephalus in a pediatric population. Neurosurg Focus 19:E8, 2005

18. Riva-Cambrin J, Detsky AS, Lamberti-Pasculli M, Sargent MA, Armstrong D, Moineddin R, Cochrane DD, Drake JM: Singha SK, Chatterjee N, Neema PK: Predicting postresection hydrocephalus in pediatric patients with posterior fossa tumors. J Neurosurg Pediatr 3:378-385, 2009

19. Ruggiero C, Cinalli G, Spennato P, Aliberti F, Cianciulli E, Trischitta V, Maggi G: Endoscopic third ventriculostomy in the treatment of hydrocephalus in posterior fossa tumors in children. Childs Nerv Syst 20:828-833, 2004

20. Sainte-Rose C, Cinalli, G, Roux F, Maixner W, Chumas PD, Mansour M, Carpentier A, Bourgeois M, Zerah M, Pierre-Kahn A, Renier D: Management of hydrocephalus in pediatric patients with posterior fossa tumors: The role of endoscopic third ventriculostomy. Neurosurg Focus 7: E3, 1999

21. Sainte-Rose C, Cinalli G, Roux FE, Maixner R, Chumas PD, Mansour M, Carpentier A, Bourgeois M, Zerah M, Pierre-Kahn A, Renier D: Management of hydrocephalus in pediatric patients with posterior fossa tumors: The role of endoscopic third ventriculostomy. J Neurosurg 95:791-797, 2001

22. Scarrow AM, Levy El, Pascucci L, Albright AL: Outcome analysis of endoscopic III ventriculostomy. Childs Nerv Syst $16: 442-445,2000$

23. Schroeder HW, Niendorf WR, Gaab MR: Complications of endoscopic third ventriculostomy. J Neurosurg 96:1032-1040, 2002

24. Tamburrini G, Pettorini BL, Massimi L, Caldarelli M, Di Rocco C: Endoscopic third ventriculostomy: The best option in the treatment of persistent hydrocephalus after posterior cranial fossa tumour removal? Childs Nerv Syst 24: 1405-1412, 2008

25. Teo C, Jones R: Management of hydrocephalus by endoscopic third ventriculostomy in patients with myelomeningocele. Pediatr Neurosurg 25:57-63, 1996 